地すべり 第25巻 第 1 号

Journal of Japan Landslide Society 25-1 (1988)

\title{
表首崩壊発生危険雨量の予測 \\ Estimation of Critical Volume of Rain to Surface Failure Occurrence
}

\author{
駒 村 富 士 弥* \\ Fujiya Komamura
}

\begin{abstract}
The condition of slope failure occurrence depend not only on rainfall but on the states of slope. The discussions from both sides of rainfall and slope may be neccessary to elucidate the condition of slope failure.

In this paper, an equation of safety factor including the degree of saturation as a parameter, in addition to the another parameters such as slope inclination, depth of soil layer, cohesion of soil, void ratio, etc. is introduced to estimate the volume of water in the soil layer at the time of occurrence of slope failure.

The critical volume of rainfall which induce the slope failure is converted from the volume of water in the soil layer which is calculated by using the equation of the safety factor.

The time to slope failure can be forecasted by knowing the time when the accumulated volume of precipitation reaches the critical volume estimated by the presented method in this paper.
\end{abstract}

\section{1. はじめに}

斜面崩壊，土石流などによる土砂災害には多量の降雨 が関係している場合が多い。しかし，このような土砂災 害の発生は降雨のみに依存するものではなく, 発生場所 の地形や土質条件にも関係するもので，降雨時の土砂災 害の発生について検討する場合には，降雨条件と発生場 所の安定条件の両方を考慮し, 両者の複合問題として取 り扱ら必要があろう。

表層崩壊の発生に関して行われた従来の研究の多くは, 降雨条件か斜面条件のいずれか一方に着目して崩壊の発 生を検討していたのであるが $1,2,3,4,5,6)$ ，最近になって， 両者, すなわち誘因と素因を組み合わせて総合的に解析 し, 崩壊発生危険雨量や発生時刻を予測しょうとする研 究も行われるようになってきた ${ }^{7,8,9)}$ 。

そこで, 本論文では, はじめに斜面の傾斜，土層の厚 さ, 土の $C, \phi$ などのほかに，土の飽和度をパラメータ ーとした安全率の計算式を導き， $F=1$ になるときの飽 和度を求めて崩壊発生危険水分量（崩壊発生危険雨量） を算定する方法を提示する。つぎに，土層がその水分量 に達するまでの時間は，降雨の量と継続時間掞よび土の 浸透能によってきまるので，それらの関係についても考 察し, 崩壊発生の場と降雨のタイプの両者を複合した斜 面崩壊発生予知の方法について検討する。

\section{2. 安全率の飽和度による変化}

山地に豪雨が降ると, その一部は地表面を流れ, 一部 は地中に浸透して崩壊の発生に関係するよらになる。雨 水の地中への浸透量は浸透がはじまった当初は大きいが， その後徐々に減少し，土が飽和すると浸透しなくなって 表面流があらわれる。これを模式的に示すと, 図一の 点線のようになる。さらに, この罒に実線で示したよう な累加雨量曲線を兄がくと，この二つの曲線の交点 $\mathrm{B}$ ま では浸透量の方が多いため, 雨の降りはじめからこのB 点の時刻までは，表面流が生じないが，それ以降は土が 飽和して表面流が生ずるようになることが示される。そ の後, 表面流量が増加し, ある量以上になったとき崩壊 が発生する場合が多いといわれている1。

しかし, 現実にはそのような例ばかりではなく, 累加 浸透量曲線と累加雨量曲線が交叉する時点より以前, す なわち土層が完全に飽和していないと思われる状態に㧊

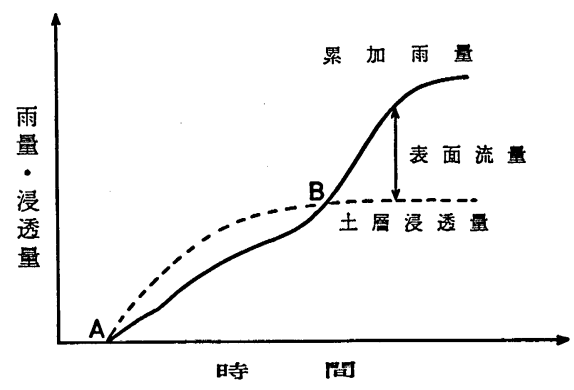

图-1 雨量, 浸透量の時間的変化（模式図）

* 東京大学燶学部 
いても，崩壊が発生する場合がある。

そこで，そのような不飽和な状態での崩壊発生につい て検討してみる。

降雨による表層崩壊の発生経過をたどってみると, 一 般的に次のよらになる。

降雨 $\rightarrow$ 斜面への雨水の浸透 $\rightarrow$ 土質の変化 $\rightarrow$ 安全率の低 下 $\rightarrow F \leqq 1 \rightarrow$ 崩壊発生

このような崩壊発生の経過を考えると, 雨水の浸透に よる土質の変化を考虑した安全率の式を導いて，崩壊の 発生を検討することが可能になる。

いま，図-2 のような傾斜角 $\theta$, 土層厚 $H$, 浸透水深 $H_{1}$ の半無限斜面を想定すると, 単位土体 $a a^{\prime} b^{\prime} b$ の すべり面に直角に働く分力は

$$
\begin{aligned}
\sigma_{v} & =\left\{\gamma_{s}\left(H-H_{1}\right)+\left(\gamma_{t}-\gamma_{w}\right) H_{1}\right\} \cos ^{2} \theta \\
& =\left\{\gamma_{s} H-\left(\gamma_{s}-\gamma_{b}\right) H_{1}\right\} \cos ^{2} \theta \quad \ldots \ldots \ldots \ldots . . .
\end{aligned}
$$

ここに, $\gamma_{s}:$ 土の単位体積重量 $\gamma_{t}:$ 飽和土の単位体積重量 $\gamma_{w}:$ 水の単位体積重量 $\left(\gamma_{t}-\gamma_{w}\right)=\gamma_{b}:$ 浮力を考虑したときの土の水 中重量

となり，斜面が粘着力 $C$ のある土からなる場合は，す ベりに抵抗する力は

$$
\begin{aligned}
\tau_{r} & =C+\sigma_{v} \tan \phi \\
& =C+\left\{\gamma_{s} H-\left(\gamma_{s}-\gamma_{b}\right) H_{1}\right\} \cos ^{2} \theta \cdot \tan \phi
\end{aligned}
$$

となる。この力 $\tau_{r}$ とすべり面に沿って下方に働く分力, $\tau=\gamma_{s} H \cdot \cos \theta \cdot \sin \theta$ との比を求めると安全率 $F$ が得ら れ，それが 1 以下の場合に崩壊が発生する。

$$
F=\frac{C+\left\{\gamma_{s} H-\left(\gamma_{s}-\gamma_{b}\right) H_{1}\right\} \cos ^{2} \theta \cdot \tan \phi}{\gamma_{s} H \cos \theta \cdot \sin \theta}
$$

ところで，浸透水深 $H_{1}$ であるが，現実には土壤水分 は図-2(b) に示したよらに, 土壤の間隙中に分散して存在 して拉り，土層内で $H_{1}$ の部分と $\left(H-H_{1}\right)$ の部分とが

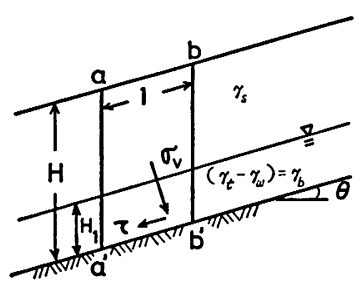

(a)

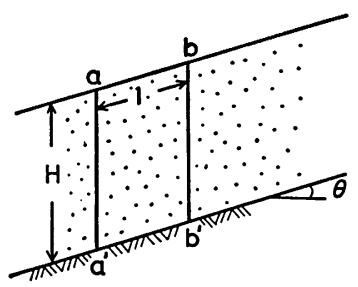

(b)

図-2 斜面の橖式図 図-2(a)のようにはっきりと分離して存在していることは 稀であろら。そこで， $H_{1}$ は通常分散して存在している 土壤水分を，もし土層の下部に集めたとしたらこの深さ になるであろら，とみなしたときの值であると考觉ると， $H_{1} / H$ は飽和度に相当するファクターとして取り扱らこ とができるので $\left(H_{1} / H\right) \times 100=S_{r}$ とし，それと $\gamma_{s}=$ $\left(G_{s}+e S_{r}\right) \cdot \gamma_{w} /(1+e)$ 执よび $\gamma_{b}=\left(G_{s}-1\right) \gamma_{s} /(1+e)$ と を用いて (3) 式の一部, $\left\{\gamma_{s} H-\left(\gamma_{s}-\gamma_{b}\right) H_{1}\right\}$ を書き改 めると

$$
\begin{aligned}
& \left\{\gamma_{s} H-\left(\gamma_{s}-\gamma_{b}\right) H_{1}\right. \\
& =\frac{\left(G_{s}+e S_{r}-e S_{r}^{2}-S_{r}\right) \gamma_{w} H}{(1+e)}
\end{aligned}
$$

ここに, $G_{s}$ : 土の比重, $e$ : 間隙比 となる。な拉，計算にあたっては， $S_{r}$ は飽和度を 100 でわった值を用いる。これを（3）式に代入して整理する と, 土首の飽和度をパラメーターとした安全率の計算式 が次のように導かれる。

$$
\begin{aligned}
F= & {\left[\left\{(1+e) C+\left(G_{s}+e S_{r}\right.\right.\right.} \\
& \left.\left.\left.-e S_{r}^{2}-S_{r}\right) \gamma_{w} H \cos ^{2} \theta \cdot \tan \phi\right\}\right] \\
& /\left[\left(G_{s}+e S_{r}\right) \gamma_{w} H \cos \theta \cdot \sin \theta\right]
\end{aligned}
$$

さらに, 粘着力 $C$, 内部摩擦角 $\phi$ も飽和度によって 変化することを考虑する必要があろら。

飽和度が增加すると土の粘着力 $C$ 扣よび内部摩摖角 $\phi$ のいずれも減少することが多くの実験によって示されて いる。これらの $C, \phi$ のら飽和度による $\phi$ の変化は あまり大きくなく, 特に表尿崩壊の場合には土被り荷重 が小さいために $\phi$ 成分がせん断抵抗に与える影悠は比較 的小さく, $C$ 成分の方が支配的であるといわれている8 。 そこで，本報では， $\phi$ は測定時の值のままほぼ一定であ り, 粘着力 $C$ は飽和度の増加によって指数関数的に減 少すると仮定し

$$
C=C_{d} \cdot \exp \left(-\alpha \cdot S_{r}\right)
$$

とする。ただし， $\alpha$ は減少係数， $C_{d}$ は乾燥時の粘着力。

これを（5）式に代入すると安全率は

$$
\begin{aligned}
F= & {\left[\left\{(1+e) C_{d} \cdot \exp \left(-\alpha \cdot S_{r}\right)+\left(G_{s}+e S_{r}\right.\right.\right.} \\
& \left.\left.\left.-e S_{r}{ }^{2}-S_{r}\right) \gamma_{w} H \cos ^{2} \theta \cdot \tan \phi\right\}\right] \\
& \left./\left[\left\{G_{s}+e S_{r}\right) \gamma_{w} H \cos \theta \cdot \sin \theta\right\}\right] \quad \ldots \ldots . .
\end{aligned}
$$

とあらわされる。

これによって，飽和度が 0 から $100 \%$ まで変化する間 の飽和度と安全率との関係を計算することができ，崩壊 発生時 $(F=1)$ の飽和度と含水比 $\left(w=e S_{r} / G_{s}\right)$ を推定で きる。

また，この考え方によれば，土層が飽和しない場合で も崩壊発生の可能性があることを説明できるわけで，従 来提唱されていた考え方, 寸なわら飽和してから崩壊が 発生するといら考方方よりも一層現実的な説明ができる ことになろら。な拈，計算上は飽和度が $100 \%$ 以上（飽 和時）でも $F$ が 1 以下にならず，斜面は安定であると 
判断される場合もでるが，このように飽和度が 100\% 以 上の場合には, 前述のよらな斜面内応力のつり合い関係 によってではなく，パイピング等他のメカニズムによっ て崩壊が発生ずると考光れば，計算上は $F>1$ となって も現実に崩壊が発生するという点は説明できよう。

\section{3. 崩壊発生危険雨量と発生時刻の予知}

前述のようにして, 降雨により表盧崩壊が発生する時 点 ( $F=1$ の時点) での飽和度が推定されると, $w=e S_{r} /$ $G_{s}$ によってそのときの含水比が求められ，その含水比 と現時点 (降雨前) の含水比との差 $\left(w^{\prime}\right)$ を計算すると, それが崩壊の発生をもたらす含水比の增加分となる。さ らに, この含水比をもとに 図-2(b)のモデル土柱 $\left(V\left(\mathrm{~m}^{3}\right)\right.$ $=1 \times 1 \times \cos \theta \times H)$ の水分量を

$$
\begin{aligned}
& W_{w}=W_{s} \times w^{\prime}=\left\{G_{s} \cdot V /(1+e)\right\} \times w^{\prime} \\
& \text { ここに, } W_{w}: \text { 水分の重量 }
\end{aligned}
$$

$W_{s}:$ 土粒子分の重量

として重量で計算したあと容積に換算し $\left(V_{w}=W_{w} / \gamma w\right)$, それを崩壊発生水分量とするとその量が降雨によって満 たされたとき崩壊が発生することになる。

地表に降った雨は一たん土層中に浸透したあとその一 部は再び地表に流出するであららから, 崩壊発生水分量 と等量の雨量がそのまま崩壊の発生をもたらす雨量（崩 壊発生危険雨量）になるとは限らないが，土層が飽和す るまでは地表流出がなく，浸透した雨がすべて土層内に 貯留されると仮定すれば, 崩壊発生水分量と等量の雨量 が崩壊発生危険雨量 $R$ となる。この $R$ は崩壊発生水分 量を地表面に拈ける水高に換算して得られる值， $R=$ $V_{w} / \cos \theta$ であり, これによって，ぞの程度の雨量で崩 壞が発生するか予測できることになる。

ここに, 一例として三重県海山町のある山腹斜面を対 象にして実施した測定および計算の結果を示す。 土質調査の結果,

$$
\begin{aligned}
& G_{s}=2.7, \quad e=1.58, \quad S_{r}=55 \%, \quad w=32.2 \%, \\
& C=0.6 \text { ton } / \mathrm{m}^{2}, \quad \phi=33^{\circ}
\end{aligned}
$$

の各值が得られた。粘着力は飽和度によって $C=C_{d}$. $\exp \left(-\alpha \cdot S_{r}\right)$ と変化するものと仮定したので，実際に は実测資料によって， $\alpha$ をさる必要がある。しかし， 現在この調査地での $C \sim S_{r}$ 関係の実測資料が無いため, ここでは飽和度が $100 \%$ のよきの $C$ は飽和度が 0 のと きの $C$ の 3 分の 2 に減少すると仮定して $\alpha=0.406$ と する。さらに，乾燥土の粘着力 $C_{d}$ は，（6）式を変形し た式 $C_{d}=C / \exp \left(-0.406 S_{r}\right)$ とより計算して $0.75 \mathrm{ton} /$ $\mathrm{m}^{2}$ とする。このような土質からなる傾斜角 $\theta=32^{\circ}$, 土 層厚 $H=1.8 \mathrm{~m}$. の斜面の 安全率の 飽和度による変化を 計算して図示すると，図一跑ようになり，飽和度が $80 \%$ すなわち含水比が $w=e S_{r} / G_{s}=46.8 \%$ になると $F=1$ となって崩壊が発生することがよみとれる。これは, 測

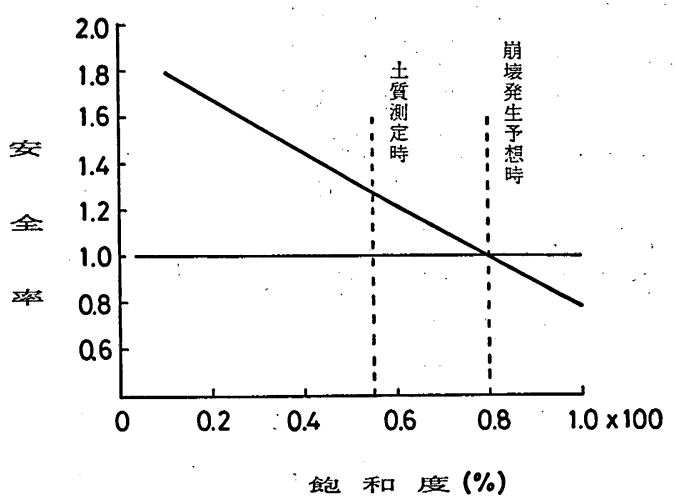

図-3 安全率の飽和度による変化（海山町）

定時点での含水比が $32 \%$ であったから，その時点より $14.6 \%$ 含水比が増加すると崩壊が 発生することを示し ている。

これをもとに， $1 \mathrm{~m} \times \cos 32^{\circ} \times 1.8 \mathrm{~m}(1.8 \mathrm{~m}$ は土層 厚）の土体中に批ける $14.6 \%$ の水分量を計算すると， $0.233 \mathrm{~m}^{3}$ となり,これを単位面積の面に拈ける水高にな 特すと $275 \mathrm{~mm}$ となる。すなわち，ここで対象とした 斜面に $R=275 \mathrm{~mm}$ の雨水が浸透すると崩壊が発生する といらことになり，これが崩壊発生危険雨量となる。

以上の計算は初期飽和度が $55 \%$ のときのものである が，長雨の後などで飽和度が $55 \%$ より高い場合を基準 飞崩壊発生危険雨量を計算すれば，それは前述の值より 低い值いになるし，乾燥していて飽和度が低い時点を基 集にすれば，崩壊発生危険雨量は大さく算定される。従 って，梅雨期や台風期には正確を期するため対象となる 斜面の飽和度をたびたび測定し，それをもとに崩壊発生 危険雨量を常に設定し直して护く必要があうう。

次に，土壤含水比が前述の量だけ増加するのにぞの位 の時間がかかるかを考光てみると，それは土の透水性に よってきまるであろう。

すなわち，前述のようにして求めた崩壊発生危険雨量 に相当する水分量が浸透するのに要する浸透時間 $t$ は浸 透能（浸透速度）を $f$ とすると，次のように計算される。

$$
t=R / f
$$

ただし， $R$ は崩壊発生危険雨量で単位は $\mathrm{mm}$ $f$ の単位は $\mathrm{mm} / \mathrm{hr}$

土中への雨水の浸透能 $f$ は, 土中の水分量の関数であ り，降雨の初期には高い值を示すが，降雨時間の経過と ともに急速に低下し，60分以上経過した後一定の浸透能 すなわち最終浸透能に達する11。

この関係は Horton によって

$$
f=\left(f_{0}-f_{c}\right) e^{-k t}+f_{c}
$$

ここに, $f_{0}$ : 初期浸透能

$$
f_{c} \text { : 最終浸透能 }
$$

と与えられているもので，最終浸透能については，いる 
いろな土袞に対する測定結果が得 られて招り ${ }^{11,12)}$ ，裸地斜面では 10 15 mm/hr 程度となっている。 そこで，漫透時間の計算にあた っては最終浸透能の值を用いるこ とにし,この調査斜面の最終浸透 能を $f_{c}=12 \mathrm{~mm} / \mathrm{hr}$ と仮定すると, $R=275 \mathrm{~mm}$ であるから，浸透時 間は約23時間と計算される。

以上は，崩壊が発生する斜面に 着目して考察した結果であるが, さらに水分の供給され方，すなわ ち雨の降り方に着目して検討して みる。

雨の強さが前述の浸透能と同じ く, $12 \mathrm{~mm} / \mathrm{hr}$ であり，それが 23 時間以上続くならば（図-4の降雨 タイプII)，雨が降り始めてからちょ らど23時間後に崩壊が発生することに なり，それょり強度の強い雨（タイプ I）が降ったとしても，それが浸透す るのに時間がかかるから，やはり崩壊 が発生するまでには23時間程度の時間 を要するものと思われる。

また， $r=12 \mathrm{~mm} / \mathrm{hr}$ より弱い雨が

長い時間続いた場合（タイプ孟）に は，23 時間以上たっても累加雨量が $275 \mathrm{~mm}$ に達するまでは崩壊が発生せ ず，275 $\mathrm{mm}$ を超えた時点で崩壊が発 生することが予想される。さらに，雨 量強度の弱い雨が長時間続いても, 累 加雨量が崩壊発生危険雨量に達しない 場合（困-4のタイプIV）は崩壊が発生 しないと判断される。

\section{4. 崩壊の発生および非発生の 事例}

昭和59年 7 月 12 日から14日にかけて, 三重県海山町で累加雨量 $166 \mathrm{~mm}$ の降 雨があったが，その時は崩壊の発生が みられなかった。これは, 雨の降りか たが図-4の降雨タイプIVに相当し降雨 量が前述の崩壊発生危険雨量に達しな かったためであると思われる（図-5）。

つづいて，同年 7 月22日から 24 日に かけて累加雨量 $314 \mathrm{~mm}$ の豪雨があり， 7 月 24 日午前 8 時頃前記斜面の近くで 崩壊が発生し，民家一棟が全壊すると

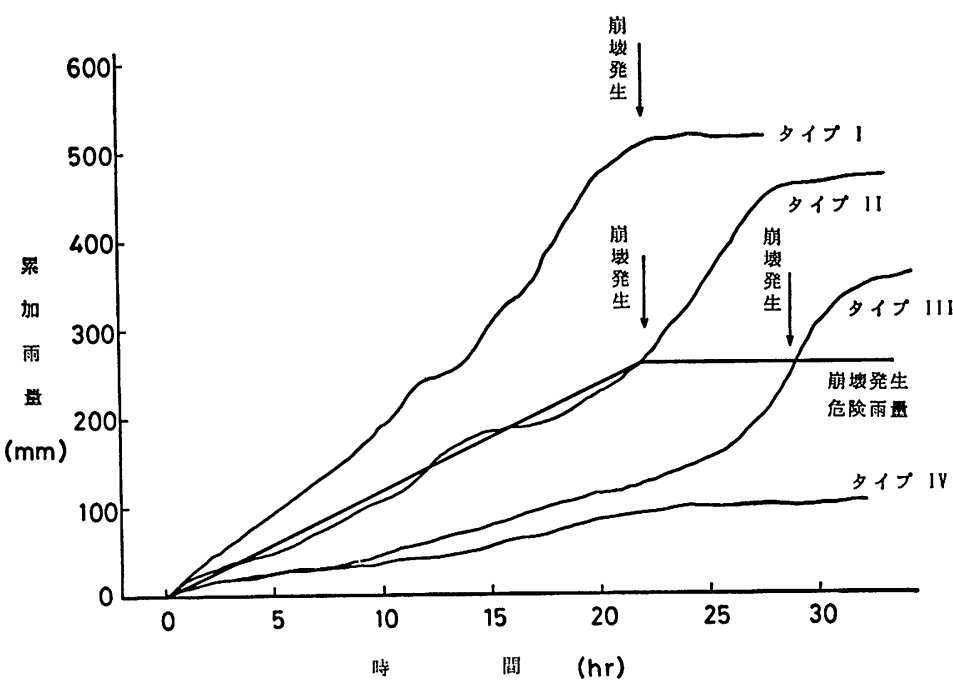

図-4 降雨タイプによる崩壊発生時刻のちがい（模式図）

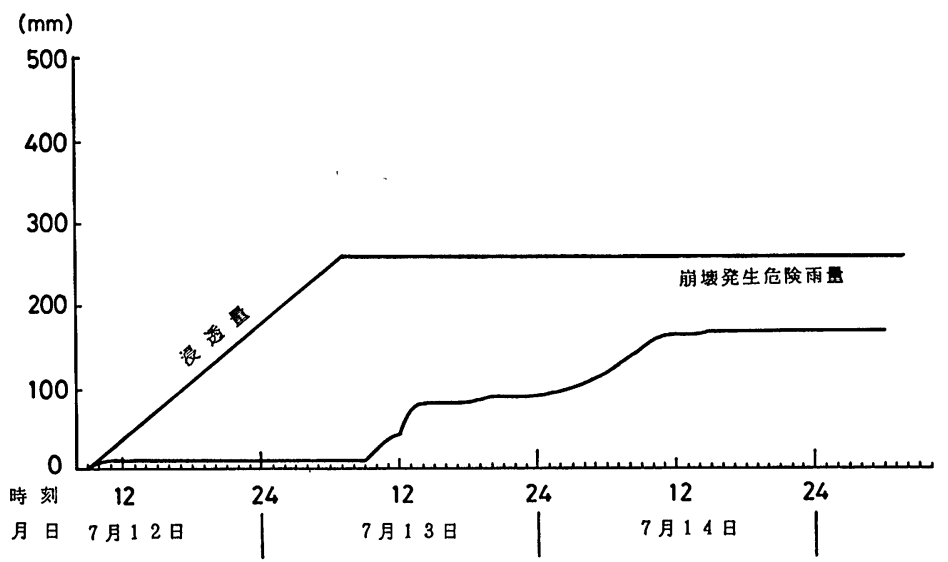

図-5 崩壊非発生の事例（海山町）

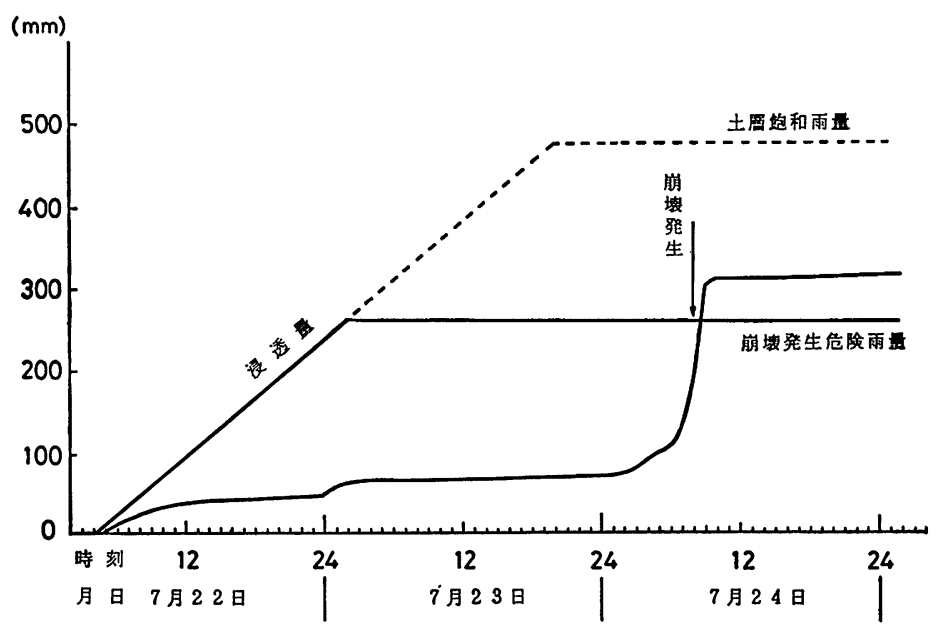

四-6 豪雨による崩壊発生の事例（海山町） 
いら被害があった。この時の雨量〜時間関係と, 前述の ようにして計算した崩壊発生危険雨量とを図示すると， 図-6のようになり，この図から累加雨量がちょうど崩壊 発生危険雨量の計算值に達した頃に崩壊が発生したこと が読み取れる。これは，図-4の降雨タイプ而を示してい るとみなされる。

つぎに, 昭和 57 年 8 月の台風 10 号による災害の事例を とりあげ，崩壊発生危険雨量について考察してみよう。

昭和57年 8 月 1 日20 22時頃, 台風10号による豪雨で, 三重県美杉村の各地に崩壊・土石流が多数発生し, 鉄道 や道路に大きな被害が生じた。このとき，村当局は降雨 の状況を判断しながら，第一次から第三次までの避難命 令を発令し，住民の避難をスムーズに行ったため死者行 方不明など人的被害は一人もなかった。

この豪雨により, 美杉村で約 470 简所の崩壊が発生し た。それらのほとんどは谷頭部に発生した比較的小規模 の表層崩壊であったが，崩壊土砂は小溪流を土石流とな って流下し，鉄道や道路を寸断して物的被害を大きくし た。

前述の崩壊発生危険雨量を求める際に用いる 土質パラメーターは美杉村内の一斜面のものを 代表して用いることとし, 土の試料は, 同村内 に在る三重大学付属演習林の一斜面から採取し た。土質試験の結果は次のと扮りであった。

$$
\begin{aligned}
& G_{s}=2.65, e=1.15, S_{r}=49 \%, w=21.3 \%, \\
& C=0.63 \mathrm{t} / \mathrm{m}^{2}, \quad \phi=34^{\circ}
\end{aligned}
$$

浸透能は前述の場合と同じで $f_{c}=12 \mathrm{~mm} / \mathrm{hr}$ とする。粘着力 $C$ は前述のように，ここでも 飽和度が $100 \%$ のときには，0\%のときの 3 分 の 2 に減少すると仮定し $C_{d}=C / \exp (-0.406$. $\left.S_{r}\right)$ より乾燥時の粘着力 $C_{d}$ を求めて, $0.77 \mathrm{t} /$ $\mathrm{m}^{2}$ とする。

傾斜角 $\theta$, 土層厚 $H$ は崩壊地の平均的な值 を採用し， $\theta=35^{\circ}, H=1.2 \mathrm{~m}$ とする。

これらの数值を用いて, 斜面の安全率の飽和

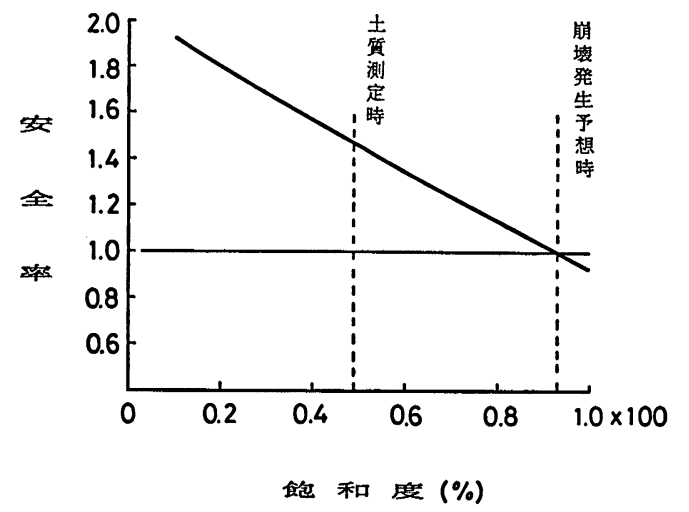

图-7 安全率の飽和度による変化（美杉村）
度による变化を計算して図示すると, 四-7のようになり, $F=1$ となるときの飽和度は $93 \%$ と推定される。さら に, 崩壊発生危険雨量と土層飽和時の雨量を計算すると, それどれ $282 \mathrm{~mm}$ と， $327 \mathrm{~mm}$ となる。

7 月 31 日から 8 月 1 日までの降雨の状況は図-8に示す とおりであった。この因に，前述のよらにして計算した 崩壊発生危険雨量を記入すると, 降雨量が崩壊発生危険 雨量に達した時点で避難命令が発令され, それより少し 招くれて崩壊・土石流が多数発生したと判断される結果 が示される。これは図-4の降雨タイプIを示しているも のといえよう。

さらに, 同じ台風10号による豪雨で発生した静岡市北 西山間部の赤沢地区の斜面崩壊の例をあげてみよう。こ の崩壊が発生した近傍の斜面に淤ける土質調查の結果は 次のと括りであった。

$$
\begin{aligned}
& G_{s}=2.69, e=1.36, \quad S_{r}=59 \%, w=29.8 \%, \\
& C=0.65 \mathrm{t} / \mathrm{m}^{2}, \quad \phi=43^{\circ}
\end{aligned}
$$

この地区の土の粘着力 $C$ 6前述のように, 飽和度が

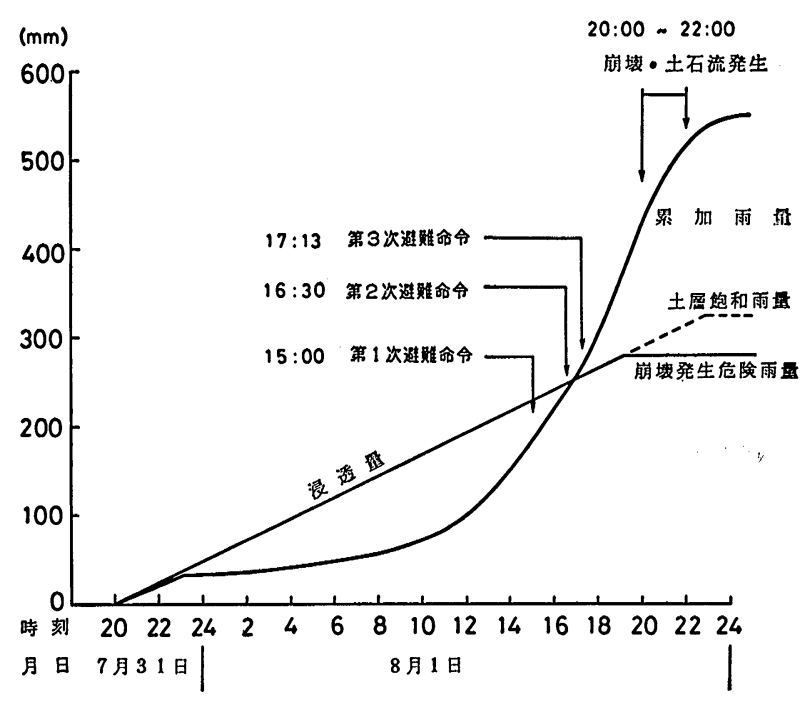

图-8 豪雨による崩壊・土石流の発生事例（美杉村）

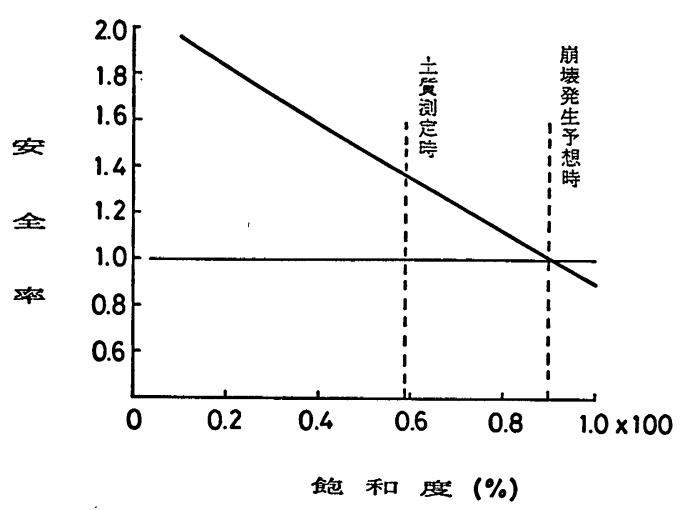

図-9 安全率の飽和度による変化（赤沢） 
100\% のときには，0\% のとさの 3 分 の 2 に減少すると仮定し, 乾燥時の粘 着力 $C_{d}$ を $0.83 \mathrm{t} / \mathrm{m}^{2}$ とする。

このような土質からなる傾斜角 40 度, 土㬝厚 $1.5 \mathrm{~m}$ の斜面の安全率の飽和度 による変化を計算して，図示すると 図-9 のようになり，F=1 となるとき の飽和度は $90 \%$ と推定される。これら の值をもとに，前述の方法によって崩 壊発生危険雨量と土首飽和時の雨量を 計算すると，それぞれ $268 \mathrm{~mm}$ と 354 $\mathrm{mm}$ となり，これを図示すると図 -10 のようになる。

さらに, この図に 7 月 31 日から 8 月 3 日までの降雨状況を記入すると,図一 4 の降雨タイプ Iに類似した降雨型を 示し, 累加雨量 (=浸透量) が先に計 算した崩壊発生危険降雨量に一致した

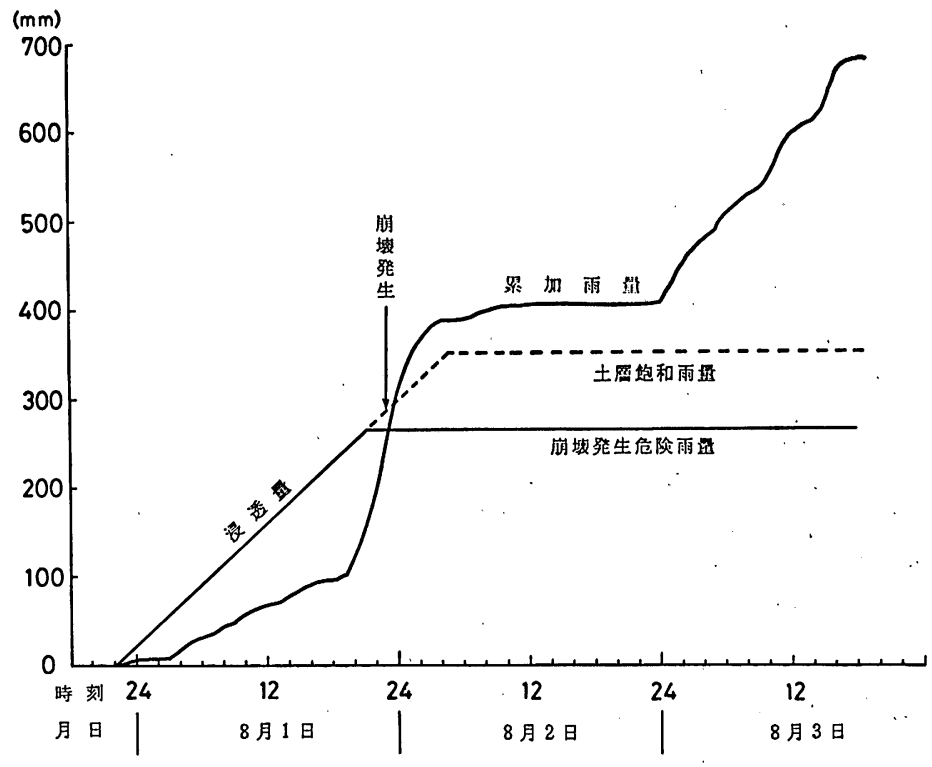

図-10 豪雨による崩壊発生の事例（赤沢） 時点で崩壊が発生したことが読み取れる。

\section{5. あとがき}

以上のように，本論文では土層の飽和度をパラメータ ーとした安全率の計算式を前き， $F=1$ になるときの飽 和度から崩壊発生に要する土風水分量を計算して崩壊発 生危険降雨量を算定するとともに，さらに雨水の浸透量 との関係を考虑して，雨の降りかた(累加雨量のふえ方) を4つのタイプに分類し，それと崩壊発生危険降雨量と の関係から㢣开避難雨是の設定扣よび避難時刻の決定の ための手がかりを得ようと試みた。な拉，ここで試みた 表層崩壊発生予測の手法は，比較的簡単に実施できるこ とを目標にしたため，斜面のモデルを単純化しているこ と，浸透能を一定にしていることなど，前提条件に多少 の問題点を含んでいるといえる゙。

また，この方法を実地に適用するにあたっての問題点 は，第一に安全率の值が，土質パラメーター，特に測定

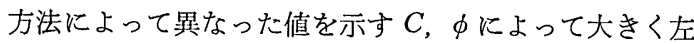
右されることであり，第二に雨量や浸透量の流出による 損失量を考虑していないことであろら。

今後, これらの問題点について検討を重ね, 一層適切 な表首崩壊発生予测の手法を確立したいと思っている。

なお，本研究を行うにあたっては，三重大学農学部の 林拙郎助教授および(財)林業さ木コンサルタンツから有 益な示唆をいただき，また同コンサルタンツからは降雨 資料など各種資料を提供していただいた。ここに記して 感謝いたします。

\section{参考文献}

1) 田中 茂: 交雨による崖崩れの問題点, 地すべり, Vol. 10, No. 3, pp. 15 20, 1974.

2）鈴木雅一，小橋澄治，がけ崩れ発生と降雨の関係につい $\tau$, 新砂防, No. 121, pp. 16 26, 1981.

3）丸井英明: 自然斜面に打ける表㬝崩壊の研究, 宗大学位論 文, 1981 .

4）沖村 孝：潜在崩土凰分布を利用した表局崩壊発生位置に 関する研究, 新砂防, No. 124, pp. 9 18, 1982.

5）沖村 孝：山腹表回崩壊発生位照の予知に関する一研究， 土木学会論文報告集, 331号, pp. 113 120，1983.

6）沖村 孝：地形要因を利用した豪雨による山腹崩塤発生位 㯰の予知システムについて，士木学会論文報告集，338号， pp. 131 138, 1983.

7）道上正規；小島英司：豪雨によるがけ崩れの発生予知につ いて, 第 17 回自然災害科学 総合シンポジウム論文集, pp. 131 134, 1980.

8）風間秀彦：土質工学的な短期のりるみと崩壊に対する降雨 条件, 文部省科学研究費自然災害特別研究「地盤の劣化々 その地域特性を考虑した崩壊危険度の評価に関する研究」 （代表 芥川真知）成果報告菁; pp. 162 186, 1985.

9）矢田部龍一，榎 明潔，八木则男：危険降雨量にもとずく 斜面崩填発生時期の予知に関する倹剧, 地すべり, Vol. 23, No. 2, pp. 1 7, 1986.

10）駒村富士弥：雨水の浸透による表厚崩壊の発生，地すべり 学会シンポシュゥム「土砂災害の実態と予知・予防上の問 題点」論文・凟料集, pp. 51 52, 1987.

11）日野幹雄, 塚本良則 他訳：カークビー新しい水文学, 朝 合書店, pp. 41 61， 1983.

12）中野秀章：森林水文学, 共立出版, 1976.

13）瀬尾克美，船崎昌継：士砂災慧（主に土石流的被害）と降 雨量について, 新砂防 89, pp. 22 28, 1974

（原稿受理日 昭和62年 9 月24日） 